Jelena Dragišić Maksimović ${ }^{*}$, Miloš Mojović Vuk Maksimović ${ }^{1}$

${ }^{1}$ University of Belgrade, Institute for Multidisciplinary Research, Belgrade, Serbia, ${ }^{2}$ University of Belgrade, Faculty of Physical Chemistry, Belgrade, Serbia
Scientific paper

ISSN 0351-9465, E-ISSN 2466-2585

UDC:632.122.13:635.63

doi: $10.5937 /$ ZasMat1603424D

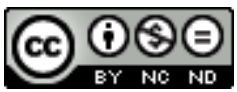

Zastita Materijala 57 (3)

424 - 429 (2016)

\title{
Silicon facilitates manganese phytoextraction by cucumber (Cucumis sativus L.)
}

\begin{abstract}
The effect of excess nutrient levels of manganese (Mn, 50 and $100 \mu \mathrm{M})$ on the growth inhibition and the appearance of Mn-toxicity symptoms in the leaves was studied in cucumber plants (Cucumis sativus L. Cv. Chinese long). Silicon (Si), when supplied as $1.5 \mathrm{mM}$ silicic acid, clearly decreased symptoms of Mn-toxicity despite approximately the same total Mn content in the leaves. In treated plants, Si improves growth and biomass production compared with that of non$\mathrm{Si}$ treated plants. Inert deposition of Si in the leaf cell walls of cucumber (a Si-accumulating species) enhanced cell wall stability. The mechanism of Si protection is proposed to act by Siinduced compartmentation of $\mathrm{Mn}$ hence increasing $\mathrm{Mn}^{2+}$-binding sites in the cell wall (e.g. Mnsilicate polymers) finally resulting in decreased toxic free $\mathrm{Mn}$ within the plant tissue rather than decrease of Mn uptake. These results suggest that Si nutrition can improve the phytoextraction potential of plants due to enhanced metal tolerance in leaf tissues.
\end{abstract}

Keywords: biomass, cell wall, EPR, Mn toxicity, phytoextraction, silicic acid.

\section{INTRODUCTION}

Manganese $(\mathrm{Mn})$ is a naturally occurring element that is found in rock, soil, and water. The major pool of manganese in soils originates from crustal sources, with various minor adjuncts including direct atmospheric deposition, wash-off or leaching from plant tissues, and the shedding or excretion of material such as leaves, dead plant, animal material and excrement. The major anthropogenic sources of environmental manganese include municipal wastewater discharges, sewage sludge, mining and mineral processing, emissions from alloy, steel, and iron production, combustion of fossil fuels, and to a much lesser extent, emis sions from the combustion of fuel additives. The environmental chemistry of manganese is largely governed by $\mathrm{pH}$ and redox conditions. $\mathrm{Mn}^{2+}$ dominates at lower $\mathrm{pH}$ and redox potential, with an increasing proportion of colloidal manganese oxyhydroxides above $\mathrm{pH}$ 5.5. Manganese in soil can migrate as particulate matter to air or water, or soluble manganese compounds can be leached from the soil.

\footnotetext{
E-mail: draxy@imsi.bg.ac.rs

Paper received: 07. 03. 2016.

Paper accepted: 19. 04. 2016.

Paper is available on the website:

www.idk.org.rs/journal
}

${ }^{*}$ Corresponding author: J. Dragišić Maksimović
$\mathrm{Mn}$ is an essential microelement for plant growth with numerous important physiological functions which specify its nutritional requirements. Different plant species or even varieties within a species have different degrees of tolerance of $\mathrm{Mn}$ toxicity. Its concentration around $100 \mathrm{mg} \cdot \mathrm{I}^{-1}$ in soil solution leads to phytotoxicity, because $\mathrm{Mn}$ ranked as middle-toxic metal [1]. Manganese toxicity is a major factor limiting crop growth causing symptoms of chlorosis, necrotic lesions, and distorted development of the leaves.

Although silicon (Si) is a major constituent of plant tissue, it is not considered to be an essential nutrient for terrestrial plants in general [2]. There are known a numerous beneficial effects of $\mathrm{Si}$ in plant resistance against biotic and abiotic stresses [3]. Protective role of $\mathrm{Si}$ in conditions of $\mathrm{Mn}$ toxicity is confirmed in cucumber [7-10].

The cultivation of plants without soil, in hydroponics - a water solution of nutrients, provides healthier, disease-free plants, with higher yield than grown in soil. Hydroponics provide complete and precise nutritional and water control, ability to manipulate nutrient levels, ability to characterize root growth and morphology, providing a clean root and shoot tissues for chemical, metabolic and molecular analysis. As the most important, hydroponics enables proper conditions to investigate the individual effects of specific elements, because in 
hydroponic systems there are fewer crossinteractions relevant to soil properties [11].

In this work we tested the effect of $\mathrm{Si}$ on $\mathrm{Mn}$ toxicity in cucumber leaves that leads to decreasing concentration of toxic free $\mathrm{Mn}^{2+}$. Maintaining plant in stabile physiologically state without toxicity symptoms, besides high Mn tissue concentrations, addition of $\mathrm{Si}$ significantly improves process of phytoextraction. Therefore, the aim of the presented work was to compare the biomass, visible symptoms and Mn concentration of cucumber plants growing in a nutrient solution with and without $\mathrm{Si}$.

\section{MATERIAL AND METHODS}

\subsection{Plant material and growth conditions}

Cucumber (Cucumis sativus L. cv. Chinese long) seeds were germinated on filter paper moistened with $2.5 \mathrm{mM} \mathrm{CaSO}_{4}$ and after $5 \mathrm{~d}$ the seedlings were transferred to a standard fullstrength nutrient solution [9]. After 7-d preculture at optimal $\mathrm{Mn}$ concentration $(0.5 \mu \mathrm{M})$, plants were subjected to different concentrations of $\mathrm{Mn}(0.5,50$, and $100 \mu \mathrm{M} \mathrm{Mn}$, respectively) for two weeks. Concomitantly, one half of the plants $(+\mathrm{Si})$ was supplied with $1.5 \mathrm{mM}$ Si as silicic acid prepared by passing $\mathrm{Na}_{2} \mathrm{SiO}_{3}$ through a column filled with cation-exchange resin (Amberlite IR-120, $\mathrm{H}^{+}$form, Fluka). Silicic acid did not change $\mathrm{pH}$ of solution after applying. The nutrient solutions were renewed completely every $2 \mathrm{~d}$ and continuously aerated. Plants were grown under controlled environmental conditions in a growth chamber with a light/dark regime of $16 / 8 \mathrm{~h}$, temperature regime of $24 / 20{ }^{\circ} \mathrm{C}$ photon flux density of $300 \mu \mathrm{mol} \mathrm{m} \mathrm{m}^{-2} \mathrm{~s}^{-1}$ at plant height, and relative humidity of about $70 \%$.

\subsection{Determination of $M n$ concentration}

After harvest, plants were oven dried at $75{ }^{\circ} \mathrm{C}$ when dry weight (DW) was measured, ashed at $550{ }^{\circ} \mathrm{C}$, and ash was dissolved in $0.5 \mathrm{M} \mathrm{HCl}$ for determination of $\mathrm{Mn}$ by atomic absorption spectrometry (AAS, Perkin Elmer 403).

\subsection{Electron Paramagnetic Resonance (EPR) measurements}

$\mathrm{Mn}^{2+}$ free and bound form were estimated modifying the method reported earlier [12]. EPR measurements were performed using a Varian E104A spectrometer (Palo Alto, CA, USA), operating at $\mathrm{X}$-band frequency $(9.5 \mathrm{GHz})$, modulation frequency $100 \mathrm{KHz}$, modulation amplitude 2 Gauss, scan range 2000 Gauss. EPR conditions were the same in all measurements. The spectra were recorded and analyzed using EW software (Scientific Software International, Inc., Lincolnwood, IL, USA).

\subsection{Statistical analysis}

Data were subjected to analysis of variance using Statistica 6 (StatSoft, Inc. USA), and means were compared by Mann-Whitney non-parametric test at $p<0.05$.

\section{RESULTS}

The development of $\mathrm{Mn}$ toxicity symptoms in the form of chlorosis with brown spots and small necrotic regions manifested at higher $\mathrm{Mn}$ concentrations is reduced by Si application (Figure 1).

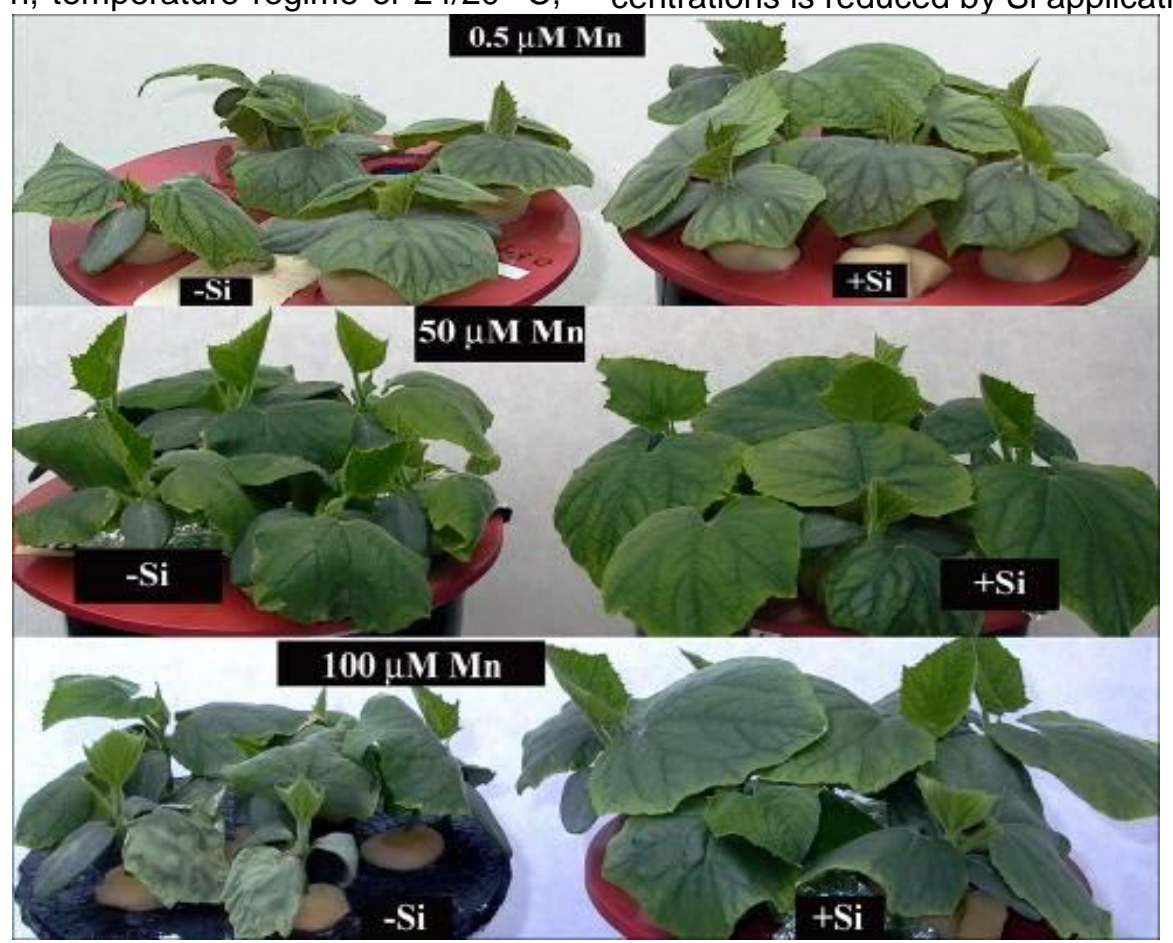

Figure 1 - Effect of root Si supply $(1.5 \mathrm{mM})$ on the development of visible symptoms of Mn toxicity in cucumber leaves 


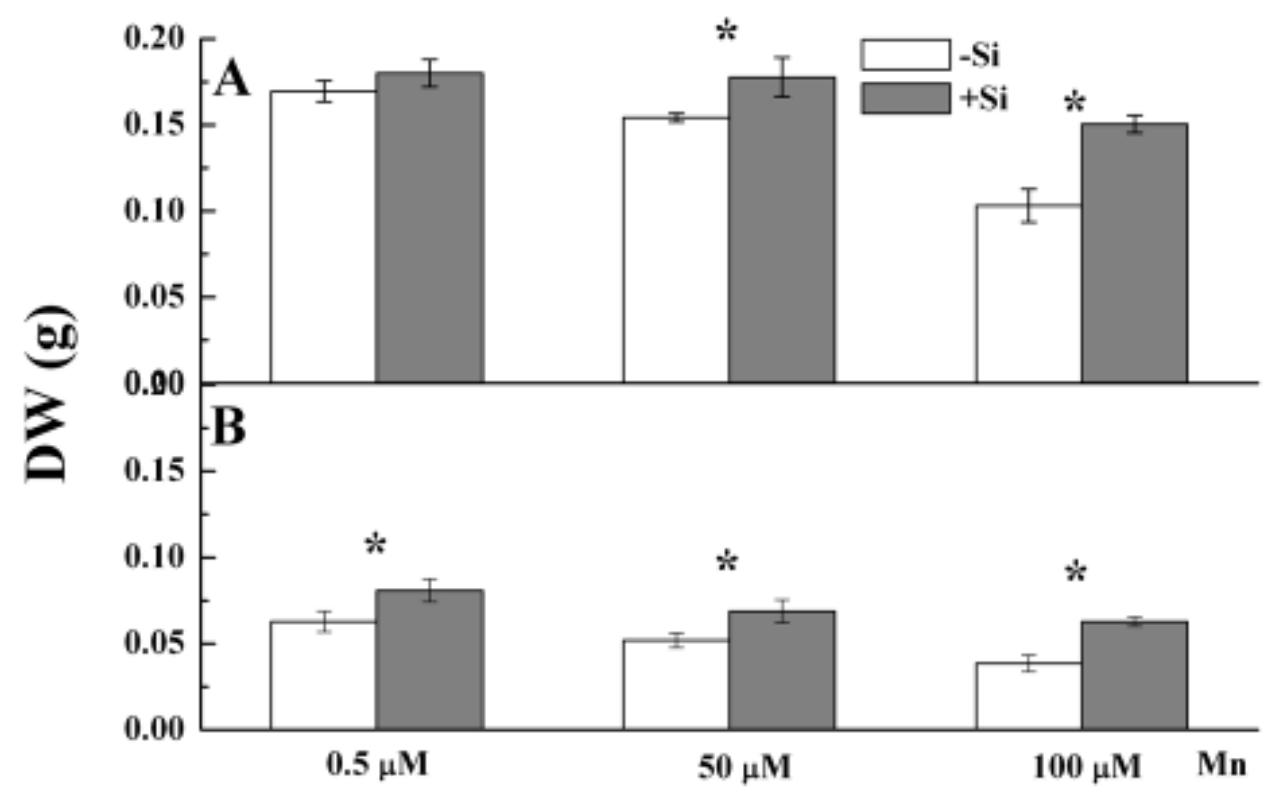

Figure 2 - Effect of root Si supply (1.5 mM) on the biomass of cucumber leaves $(A)$ and roots $(B)$ grown in the nutrient solutions with various Mn concentrations. Data are means of three replications $\pm S D$. Within the same Mn level, bars marked with * indicate a significant difference at $p<0.05$

Si stimulates root growth $(+\mathrm{Si})$ at $\mathrm{Mn}$ excess. The leaf dry weight of non-Si treated plants (-Si) was slightly lower in control, but Mn excess caused biomass reduction of $-\mathrm{Si}$ plants significantly when compare with + Si plants (Figure 2).

Figure 3 shows that $-\mathrm{Si}$ roots had significantly higher $\mathrm{Mn}$ concentration compared to the + Si roots exceptionally in control. On the contrary, there is no significant differences in leaves $\mathrm{Mn}$ concentrations between $-\mathrm{Si}$ and + Si plants.

Results of EPR measurements showed that potentially toxic free $\mathrm{Mn}^{2+}$ content in cucumber tissue depends on $\mathrm{Si}$ supplying in the nutrient solution (Table 1). Applying of $\mathrm{Si}$ along with high $\mathrm{Mn}$ concentrations in cucumber plants resulted in higher amount of non-toxic wall-bounded $\mathrm{Mn}^{2+}$ than those from $-\mathrm{Si}$ plants within the same $\mathrm{Mn}$ treatment.

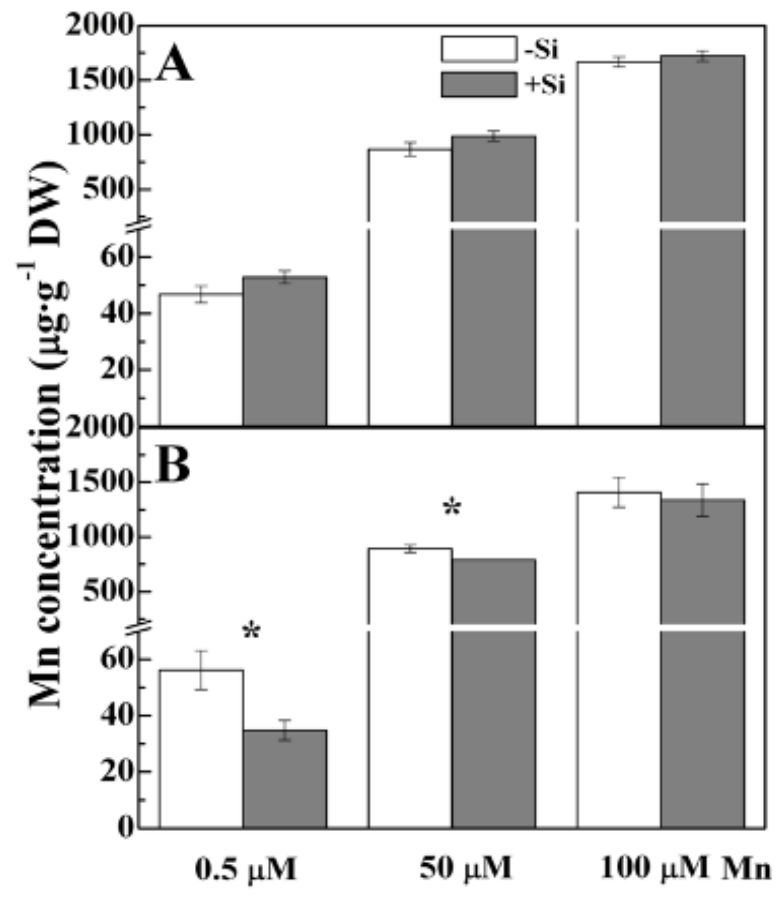

Figure 3 - Effect of root Si supply (1.5 mM) on the Mn concentrations in cucumber leaves $(A)$ and roots $(B)$ grown in nutrient solutions with various Mn concentrations. Within the same Mn level, bars marked with * indicate a significant difference at $p<0.05$. 
Table 1 - Effect of root Si supply $(1.5 \mathrm{mM})$ on the ratio of free and wall bound $\mathrm{Mn}^{2+}$ concentrations in cucumber roots and leaves grown in nutrient solutions with various Mn concentrations

\begin{tabular}{|c|c|c|c|c|c|}
\hline $\begin{array}{c}\text { Mn supply } \\
{[\mu \mathrm{M}]}\end{array}$ & \multirow{2}{*}{ Si supply } & \multicolumn{2}{|c|}{ Root } & \multicolumn{2}{|c|}{ Leaf } \\
\cline { 3 - 6 } & & Free Mn [\%] & Cell wall bound Mn [\%] & Free Mn [\%] & Cell wall bound Mn [\%] \\
\hline \multirow{2}{*}{0.5} & $-\mathrm{Si}$ & 31 & 69 & 28 & 72 \\
\cline { 2 - 6 } & $+\mathrm{Si}$ & 20 & 80 & 18 & 82 \\
\hline \multirow{2}{*}{50} & $-\mathrm{Si}$ & 11 & 89 & 45 & 55 \\
\cline { 2 - 6 } & $+\mathrm{Si}$ & 9 & 91 & 23 & 77 \\
\hline \multirow{2}{*}{100} & $-\mathrm{Si}$ & 17 & 83 & 50 & 50 \\
\cline { 2 - 6 } & $+\mathrm{Si}$ & 12 & 88 & 13 & 87 \\
\hline
\end{tabular}

\section{DISCUSION}

There is considerable inter- and intra-specific variation among $\mathrm{Mn}$ levels that induce toxicity as well as the symptoms of this toxicity in plant species [13]. The symptoms of manganese toxicity depend on the sensitivity of the plant species, but the cucumber is known as medium-tolerant plants [13]. In the plant tissue, manganese generally tends to accumulate predominantly in the shoot than in the root [14]. The signs of Mn accumulation were observed primarily in the periphery of the oldest leaves which are more sensitive to increased manganese content in them [15]. The appearance of symptoms of toxicity is not directly proportional to the amount of $\mathrm{Mn}$. In the leaves of $+\mathrm{Si}$ and $-\mathrm{Si}$ plants $\mathrm{Mn}$ content is very similar (Figure 3), while the symptoms of toxicity completely absent at + Si plants (Figure 1 ).

Manganese exists in the environment in two main forms: $\mathrm{Mn}^{2+}$ and $\mathrm{Mn}^{4+}$. Transition between these two forms occurs via oxidation and reduction reactions that may be abiotically or microbially mediated [16]. $\mathrm{Mn}^{2+}$ form is available for plants and can be readily transported from the soil into the root cells further translocated to the shoots, where it is finally accumulated [17]. A fast $\mathrm{Mn}$ transport from roots to shoots [14] was additionally stimulated by $\mathrm{Si}$ since the root $\mathrm{Mn}$ concentration was lower in $+\mathrm{Si}$ compared to $-\mathrm{Si}$ plants with simultaneously higher $\mathrm{Mn}$ concentration in corresponded leaves (Figure 3).

Biomass comparison showed beneficial effect of $\mathrm{Si}$ on growth of cucumber roots in control and under $\mathrm{Mn}$ toxicity conditions (Figure 2) as previously reported in other plant species [8, 18. 19]. On the other hand, Si significantly affected leaf biomass production in $\mathrm{Mn}$ excess (50 and $100 \mu \mathrm{M})$.

In some species (e.g. rice) $\mathrm{Si}$ reduces $\mathrm{Mn}$ uptake [20], but our results indicated that in cucumber Si supply alleviates $\mathrm{Mn}$ toxicity by decreasing the concentration of soluble $\mathrm{Mn}^{2+}$ through the enhanced adsorption of $\mathrm{Mn}$ to the cell walls (Table 1). Correspondingly, earlier investigations showed that $\mathrm{Si}$ redistribute $\mathrm{Mn}$ in leaves, foremost by stimulation of $\mathrm{Mn}$ binding to the cell wall, thus preventing potentially toxic free $\mathrm{Mn}^{2+}$ accumulation in metabolically active leaf parts $[10,21]$.

So far, scientific data revealed that plants uptake and translocate $\mathrm{Si}$ in chemical inert form as silicic acid $\left(\mathrm{Si}(\mathrm{OH})_{4}\right)$ which precipitates in cell wall forming phytoliths [22]. Compartmental analyses of Si-treated cucumber leaves pointed that more than $90 \%$ of $\mathrm{Si}$ is wall-bounded [23]. Therefore, Si facilitates a stronger cell wall-binding of $\mathrm{Mn}$ enhancing Mn detoxification.

The accumulation of $\mathrm{Si}$ in the shoots may be related to a number of factors such as transpiration, growth duration, growth rate, but root uptake ability is the most important factor for determining $\mathrm{Si}$ accumulation in the shoots. The Si concentration in the xylem sap of cucumber increase fast reaching the maximum after $30 \mathrm{~min}$ and remained stable throughout the experiment period [24]. Si pretreatment could have an alleviative effect on $\mathrm{Mn}$ toxicity only in the simultaneous presence of high $\mathrm{Mn}$ concentrations and their simultaneously availability to the plant. If their availability alternate despite the adopted silicon the symptoms of toxicity will occur [3].

EPR measurements of $\mathrm{Mn}^{2+}$ free and cell wallbound form in snap bean demonstrated that signal intensity of bounded $\mathrm{Mn}^{2+}$ is stronger in presence of $\mathrm{Si}$, probably as a result of its complexation to wall compounds [25]. The same pattern was observed in EPR measurements of our cucumber samples, as can be seen in the Table 1 . Comparing root and leaf samples far higher concentration of free $\mathrm{Mn}^{2+}$ can be observed in leaves, indicating its rapid root to shoot translocation. Hence, our results support the hypothesis of $\mathrm{Si}$ protective role in quenching detrimental (inter)actions of free $\mathrm{Mn}^{2+}$ within plant tissue. 
Accumulation of such high levels of heavy metals is highly toxic and would be lethal for the common nonaccumulator plant. Therefore it is very important to choose the appropriate plant species for the remediation purpose. Most metal hyperaccumulators are slow growing and produce little biomass which severely limits their use for the environment cleanup. Addition of Si could upgrade their biomass production rendering them convenient for phytoextraction.

Blaylock and Huang [26] concluded that the limiting step for metal phytoextraction is the longdistance translocation from roots to shoots. Cucumber exhibits a fast root-to-shoot transport with the significant metal accumulation into the shoot expressing potential capacity for phytoextraction. In this sense, cucumber can be the plant of choice. In cucumber tissue Si enhanced phytoextraction providing Mn-toxicity protection simultaneously enabling biomass production large enough to uptake, translocate and accumulate $\mathrm{Mn}$ in leaves for highly effective phytoextraction, while the cell wall-bound $\mathrm{Mn}$ fraction could be easily removed by harvesting shoot biomass.

\section{CONCLUSION}

The Mn concentration of the cucumber tissue correlated positively with the severity of Mn-toxicity symptoms and negatively with the Si supply. This strong correlation is evidence that Si-mediated binding of $\mathrm{Mn}$ to the cell wall is the main mechanism of increased $\mathrm{Mn}$ tolerance in cucumber. Taking into account this $\mathrm{Mn}-\mathrm{Si}$ interaction, cucumber, as easily harvestable plant, could have the potential use in the phytoextraction process on sites with light to moderate toxic Mn contamination with the simultaneously $\mathrm{Si}$ application.

\section{Acknowledgements}

This paper was supported by the Serbian Ministry of Education, Science and Technological Development (grant 173040).

\section{REFERENCES}

[1] H.J.M.Bowen (1966) Trace elements in biochemistry, Academic Press, the University of Michigan, USA.

[2] E.Epstein (1994) The anomaly of silicon in plant biology, Proceedings of the National Academy of Sciences, 91(1), 11-17.

[3] K.Iwasaki, P.Maier, M.Fecht, W.J.Horst (2002) Leaf apoplastic silicon enhances manganese tolerance of cowpea (Vigna unguiculata), Journal of Plant Physiology, 159(2), 167-173.

[4] Y.Liang, Q.I.N.Chen, Q.Liu, W.Zhang, R.Ding (2003) Exogenous silicon (Si) increases antioxidant enzyme activity and reduces lipid peroxidation in roots of salt-stressed barley (Hordeum vulgare L.), Journal of Plant Physiology, 160(10), 1157-1164.
[5] Y.C.Liang, W.C.Sun, J.Si, V.Römheld (2005) Effects of foliar- and root-applied silicon on the enhancement of induced resistance to powdery mildew in Cucumis sativus, Plant Pathology, 54(5), 678-685.

[6] J.F.Ma, N.Yamaji (2006) Silicon uptake and accumulation in higher plants, Trends in Plant Science, 11(8), 392-397.

[7] Q.Shi, Z.Bao, Z.Zhu, Y.He, Q.Qian, J.Yu (2005) Silicon-mediated alleviation of $\mathrm{Mn}$ toxicity in Cucumis sativus in relation to activities of superoxide dismutase and ascorbate peroxidase, Phytochemistry, 66(13), 1551-1559.

[8] W.J.Horst, H.Marschner (1978) Effect of silicon on manganese tolerance of bean plants (Phaseolus vulgaris L.), Plant and Soil, 50(1), 287-303.

[9] H.Rogalla, V.Römheld (2002) Role of leaf apoplast in silicon-mediated manganese tolerance of Cucumis sativus L, Plant Cell and Environment, 25(4), 549-555.

[10] D.E.Williams, J.Vlamis (1957) The Effect of Silicon on Yield and Manganese-54 Uptake and Distribution in the Leaves of Barley Plants Grown in Culture Solutions, Plant Physiology, 32(5), 404 409.

[11] M.Torabi, A.Mokhtarzadeh, M.Mahlooji (2012) The Role of Hydroponics Technique as a Standard Methodology in Various Aspects of Plant Biology Researches, book Hydroponics - A Standard Methodology for Plant Biological Researches, InTech, Shanghai, China, p 113-134.

[12] G.Bacic, M.R.Niesman, R.L.Magin, H.M.Swartz (1990) NMR and ESR study of liposome delivery of $\mathrm{Mn}^{2+}$ to murine liver, Magnetic Resonance in Medicine, 13(1), 44-61.

[13] C.D.Foy, B.J.Scott, J.A.Fisher (1988) Genetic differences in plant tolerance to manganese toxicity, book Manganese in soils and plants, Kluwer Academic Publishers, The Netherlands, p 293-307.

[14] V.Page, U.Feller (2005) Selective transport of zinc, manganese, nickel, cobalt and cadmium in the root system and transfer to the leaves in young wheat plants. Annals of botany, 96(3), 425-434.

[15] M.M.Fecht-Christoffers, H.P.Braun, C.LemaitreGuillier, A.VanDorsselaer, W.J. Horst (2003) Effect of manganese toxicity on the proteome of the leaf apoplast in cowpea, Plant physiology, 133(4), 1935-1946.

[16] P.D.Howe, H.M.Malcolm, S.Dobson (2004) Sources of environmental exposure, Manganese and its compounds: environmental aspects, (IPCS) I.P.o.C.S., World Health Organization, Geneva, Switzerland, p 8-10.

[17] H.Marschner (1995) Mineral plant nutrition of higher plants, Academic Press, London, UK.

[18] K.Iwasaki, A.Matsumura (1999) Effect of silicon on alleviation of manganese toxicity in pumpkin (Cucurbita moschata Duch cv. Shintosa), Soil Science and Plant Nutrition, 45(4), 909-920.

[19] W.Wrazidlo, K.Schmidt (1971) Auswirkungen von Mn-Uberschuss auf sauren Boden und 
Moglichkeiten seiner Verhinderung, Archiv Für Acker- und Pflanzenbau und Bodenkunde, 15797 804

[20] J.F.Ma, E.Takahashi (1991) Effect of silicate on phosphate availability for rice in a P-deficient soil, Plant and Soil, 133(2), 151-155.

[21] J.Dragišić Maksimović, M. Mojović, V.Maksimović, V.Römheld, M.Nikolic (2012) Silicon ameliorates manganese toxicity in cucumber by decreasing hydroxyl radical accumulation in the leaf apoplast, Journal of Experimental Botany, 63(7), 2411-2420.

[22] J.A.Raven (2003) Cycling silicon - the role of accumulation in plants, New Phytologist, 158(3), 419-421.

[23] H.Wiese, M.Nikolic, V.Römheld (2007) Silicon in Plant Nutrition, book The Apoplast of Higher Plants:
Compartment of Storage, Transport and Reactions: The significance of the apoplast for the mineral nutrition of higher plants, Springer Dordrecht, Netherlands, p 33-47.

[24] N.Mitani, J.F.Ma (2005) Uptake system of silicon in different plant species, Journal of Experimental Botany, 56(414), 1255-1261.

[25] C.D.Foy, J.C. de Paula, J.A.Centeno, E.I.Jücker (1999) Electron paramagnetic resonance studies of manganese toxicity, tolerance, and amelioration with silicon in snapbean, Journal of Plant Nutrition, 22(4-5), 769-782.

[26] M.J.Blaylock, J.W.Huang (1999) Phytoextraction of metals, book Phytoremediation of Toxic Metals: Using Plants to Clean up the Environment, John Wiley \& Sons Inc, New York, NY, USA, p 53-70.

\section{IZVOD}

\section{SILICIJUMOM OLAKŠANA FITOEKSTRAKCIJA MANGANA KOD KRASTAVCA (Cucumis sativus L.)}

Efekat visokih koncentracija mangana (Mn, 50 i $100 \mu \mathrm{M})$ na inhibiciju rasta i pojavu simptoma toksičnosti mangana u listovima je ispitivan kod krastavca (Cucumis sativus L. sorta Chinese long). Silicijum (Si), kada je dodat hranljivom rastvoru kao $1.5 \mathrm{mM}$ ortosilicijumska kiselina, jasno umanjuje simptome fitotoksičnosti mangana i pored sličnog ukupnog sadržaja Mn u listovima. U tretiranim biljkama, Si poboljšava rast i proizvodnju biomase u poređenju sa netretiranim biljkama. Deponovanje inertnog Si u lignifikovanim ćelijskim zidovima lista krastavaca (koji inače spada u Si-akumulirajuće vrste) povećava stabilnost ćelijskog zida. Predloženi mehanizam zaštite je Sipodstaknuta kompartmentacija Mn povećavanjem mesta akumulacije $\mathrm{Mn}^{2+}$ u ćelijskom zidu (npr. Mn-silikatni polimeri) što konačno rezultira smanjenjem toksičnog slobodnog $\mathrm{Mn}^{2+}$ u biljnom tkivu. Naši rezultati pokazuju da dodavanje Si u hranljivi rastvor može poboljšati potencijal biljaka za fitoekstrakciju usled povećane tolerancije metala u tkivima listova.

KIjučne reči: biomasa, ćelijski zid, EPR, toksičnost mangana, fitoekstrakcija, silicijumska kiselina.

\section{Naučni rad}

Rad primljen: 07. 03. 2016.

Rad prihvaćen: 19. 04. 2016.

Rad je dostupan na sajtu: www.idk.org.rs/casopiss 